\title{
Carbinoxamine Maleate
}

National Cancer Institute

\section{Source}

National Cancer Institute. Carbinoxamine Maleate. NCI Thesaurus. Code C47432.

An ethanolamine class of $\mathrm{H} 1$ antihistamines with mild antimuscarinic and sedative properties. Carbinoxamine diminishes the typical histaminergic effects on $\mathrm{H} 1$-receptors in bronchial smooth muscle, capillaries, and gastrointestinal smooth muscle, including vasodilation, bronchoconstriction, increased vascular permeability, pain, itching, and spasmodic contractions of gastrointestinal smooth muscle. Carbinoxamine maleate is used to provide symptomatic relieve of allergic symptoms. 